\title{
Social Perception of the Green Roofs in Contribution to Urban Sustainability: Istanbul
}

\author{
Tuba Sari Haksever* \\ Istanbul Metropolitan Municipality, 15 Temmuz Sehitleri Street No: 5, Istanbul 34134, Turkey \\ Ilkim Markoc \\ Faculty of Architecture, Yildiz Technical University, Barbaros Boulevard, Istanbul 34347, Turkey
}

\begin{abstract}
As a solution to the rapid urbanization problem, green roof applications in urban centers have gained popularity. This study aims to investigate the green roof awareness of the casual users of Zorlu Center located in Besiktas, Istanbul. The social perception of the green roof, which is defined as an urban balcony, -by its architect, located in an intensively used area, has been handled as a case study. Perception enables people to critique, interpret, distinguish, and analyze their environment according to their core values to adapt to the environment. In this study, the perception has been associated with socio-demographic characteristics such as age, education, and attitudes. A field survey, designed to measure the impact of the green roof, was conducted with the 100 users of Zorlu Center. The most significant result of this study is that most of the participants are aware of the need to develop green roofs in Istanbul. This study shows that the commercial environment in the urban area, which has green elements such as the green roof, helps to renew and revitalize the city. It has been found that the green roof application of Zorlu Center attracted the users from the settlements in its close vicinity. The people came to Zorlu Center, especially to this green area, for leisure time activities. The green roof application of Zorlu Center has positively affected the users in terms of physical and mental health. Also, it has been found that green roof applications have a contribution to sustainable urban development, especially in high-density city centers, considering the positive effects on the city silhouette and urban quality of life.
\end{abstract}

Keywords: Green roofs, shopping centers, perception, urban sustainability

DOI: $10.7176 / \mathrm{DCS} / 10-4-08$

Publication date: April $30^{\text {th }} 2020$

\section{Introduction}

Due to the employment opportunities in the cities with the Industrial Revolution, there has been an intense migration from rural to urban areas (Qian et al., 2020). There has been a rapid construction process to meet the housing needs of the increasing population in the cities (Wolch et al., 2014). Unplanned high-speed urban development has led to the destruction of green areas ( $\mathrm{Li}$ et al., 2019). In this process, urbanization, which has been realized within the framework of the principles of sustainable urban development, has been becoming a crucial requirement for the physical and mental health of future generations (Alcock et al., 2014).

The changing nature of the city and the urban lifestyle have removed people from natural environments ( $\mathrm{Li}$ et al., 2019). The green areas that should be located in the city have been replaced with concrete structures of high-density housing and office buildings (Seyfang, 2010). In metropolitan cities, the increasing number of buildings in proportion with the population causes a decrease in open green areas, especially in urban centers, and an increase in problems such as traffic and infrastructure (Newman, 2016). The emerging problems of air pollution and urban heat island as an inevitable result (Santamouris, 2014), lead to the problem of decreasing the quality of life of urban residents (Singh \& Verma, 2017). One of the effective solutions to regaining the green areas in the city is to recover the planting areas from the destructive structures; to build these roofs green (Green et al., 2017).

In Turkey, as well as around the world, new housing areas are being developed in the cities as a result of the housing needs of the increasing urban population (Bakir Yigitbas, 2018). Based on the idea of evaluating and transforming the unused parts of existing buildings located in the city center, "functionalizing and transforming the roofs," is a new approach in sustainable urban transformation (Nawaz et al., 2015). As the roof surface can be converted into a useful area, the building becomes economically and functionally more efficient and has a better impact on the city (Morau et al., 2017; Lee et al., 2015).

A few studies have been conducted in the literature about green roof perception of people. For this reason, it was necessary to conduct a study to investigate the level of awareness of the presence of green roofs in the urban center (Kuper, 2009; Zahir et al., 2014). In this respect, it was decided to carry out the case study in Zorlu Center, a famous shopping and living place for Istanbul. The study aims to investigate the perception of green roof applications as a tool for sustainable urban development. Within this scope; a questionnaire was designed to investigate (1) the awareness and the perception of the green roofs for the different age groups, (2) the awareness of the contribution of green areas to the urban life quality and (3) to determine the awareness of the advantages 
and disadvantages of green roofs.

In this context, the case study was based on 3 main sections:

- In the first part of the article, three basic concepts such as perception, green roof, and sustainability were selected, and these concepts were discussed within the literature.

- In the second part, a case study was designed to achieve the purpose of the study. In this section, field research is defined, and collected data were presented.

- In the third part, the field findings were evaluated with the literature, and the results of the article were put forward.

\section{Conceptual Framework}

Sustainable building design aims to achieve a safe, efficient external environment and interior space with the effective use of water, energy, and other natural resources while minimizing the impact on the environment. Buildings are built with the use of resources to a large extent and cause energy consumption and environmental pollution (Pinter-Wollman et al., 2018). Green roofs develop innovative approaches to the flow of rainwater by improving energy performance (Akther et al., 2018), air quality and urban ecosystem of buildings without the use of any additional reinforcement (Sutton, 2015; Hashemi et al., 2015; Francis et al., 2017). Green roofs are essential systems in sustainable building design with these features (Vijayaraghavan, 2016).

\subsection{Perception}

The environment is a set of relations in which natural, human, economic, and cultural elements are intertwined and interacted with each other. Every human being has the ability to perceive environmental relations differently. Perception enables people to criticize, interpret, distinguish, and analyze their environment according to their internal values to adapt (Villagra Islas \& Gastón Vergara, 2012).

Perception literature is used in many areas such as psychology, environmental problems, humanity, and sustainable development because of its essential contributions to these areas (Varey, 2017). Perception is the awareness of the process, taking place in the environment and the process of identification (Goodey, 1971; Kopec, 2006).

Many studies show that people's perception of their environment is influenced by demographic factors (Erickson et al., 2002; Kopec, 2006). According to Zube et al. (1982); the perception in the landscape is also influenced by the individual's memory and experiences, background culture, beliefs, and preference (Abkar et al., 2011; Taylor, 2009).

According to Bechtel et al. (1987), the "Biosphere" theory, human perception remains influenced by the social value and built environment. Figure 1 shows the relationship between humans and the biosphere.

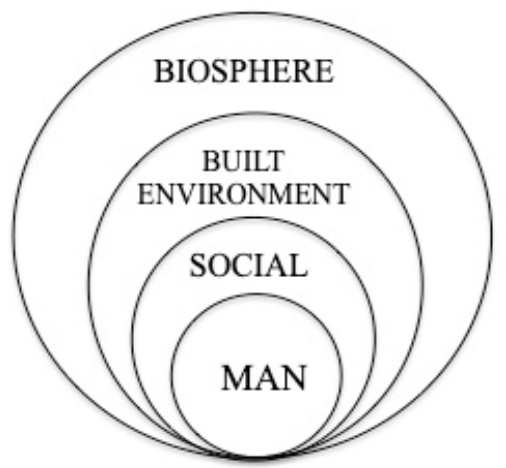

Figure 1. Relationship between human perception, social value and built environment factor (Bechtel et al. ,1987)

Every human being has a unique level of awareness; people's needs and requests are shaped and developed in this direction (Getter et al., 2009). Environmental perception and behavior in evaluating human and space relations have multiple points of view. Human behaviors are influenced by how people perceive the environment and how this perception affects human behavior. In the environmental perceptions of people, all-natural, and human components of cities and their environment are effective (Lynch, 1964).

In this study, social value has been associated with demographic characteristics as age, education, familiarity, culture, and behavior. Build environment represents the relationship between human and humanmade. Findings from previous research on human perceptions of the environment indicate that most humanmade changes or human-made structures have a substantial impact on human perception (Benjamin et al., 2007).

\subsection{Urban Sustainability and Green Roof Concept}

The green roof is one of the new approaches in the field of architecture and urbanism, which is derived from the concept of sustainable development and is used to increase the urban green space per capita by raising the 
quality of the environment in cities (Hasim et al., 2018). As green roofs provide ecosystems for planting on the roofs of buildings, they also provide an ideal living space alternative for the urban environment (Ansari \& Keshtkar, 2006; Coma et al., 2018).

The green roof is described as a roof covered with vegetation. In history, planting practices on structures have been used by ancient civilizations for centuries for both aesthetic and environmental benefits (Berardi et al., 2014). The construction of green roofs dates back to the 7th and 8th centuries BC (Jim, 2017). Instead of these aesthetic purposes, they have been replaced by green roofs for environmental benefits.

Green roof concept includes all kinds of planting applications on the roof surface; and also it is designed to provide local, social and ecological benefits at the highest level and to balance the surface area with water, soil and plant elements (Peck \& Kuhn, 2003; Clark et al., 2008). Green roofs, which are ecologically new vehicles (Benvenuti, 2014), can be defined as covering vegetation that requires minimum maintenance and irrigation, with minimal changes in the structure of existing buildings or without requiring any changes on the conventional roof (Wong et al., 2005).

Green roofs are defined in a framework that includes ecological, economic, and social components for the creation of sustainable urban spaces (Velazquez, 2005). Ecological benefits of green roofs include; reducing urban heat island (Di Giuseppe \& D'orazio, M., 2015), reducing air pollution (Hashemi et al., 2015), improving air quality through carbon capture (Getter et al., 2006; Li \& Babcock, 2014) and improving rainwater management and quality (Stovin, 2010).

Among the economic benefits, it increases the value of the property with the aesthetic and practical thermal conductivity and energy saving (Ascione et al., 2013). In terms of social benefits, green roofs provide significant open space and have a positive effect on human health (Dunnett \& Kingsbury, 2004).

These systems formed by plants; depending on the types of plants to be used in the roof and the characteristics of the sub-system elements required for the plants to live optimally, they can be divided into 2 groups as extensively and intensively.

When the characteristics of the two systems related to green roof applications are examined, it is seen that the extension systems have more straightforward application features than the intense systems. However, the simple approach in practice makes the selection of plants and habitats more challenging and complex. Extensive roofs have low weight, low cost of capital, low plant diversity and require minimal maintenance, but intensive green roofs require deep soil and higher weight, higher capital cost, increase plant diversity and require more maintenance (Liu, 2004)

The initial costs of green roof applications are higher than a typical roof application. While the initial installation cost for a simple roof is the US \$ 10 per square meter, the installation cost of an extensible roof is estimated to be about the US \$ 270 per square meter. Maintenance costs for extensible and intense green roofs range from $\$ 8$ to $\$ 11$ per square meter. When the plants completely cover the roof in the extensible roofs, the cost decreases, while on the intense roofs, these costs remain constant (Wong et al., 2005).

In today's sense, green roofs were introduced in Germany and Switzerland in the early 1960s. In the 1980s, green roof applications gained momentum in Germany, and in 1989 one million square meters of the green square, the area was found in Germany. In this rapid development, the government's encouragement of green roof practices has played an important role. Furthermore, there are indirect subsidies supported by the government in Germany for green roof applications (Stater, 2008).

The green roof applications, climate change, and energy began to be examined because of the advantages they offer in terms of efficiency in Turkey and begin to attract the attention of users and designers. Since 2003, green roofs are being implemented in Turkey. Green roofs are accepted as one of the essential elements of sustainable architecture as the equivalent of the lost green areas as a result of urbanization.

\section{Case Study}

In this section, field study methods and results will be presented in the context of the subjects discussed in the conceptual framework.

\subsection{Research Design}

Zorlu Center, as a major shopping complex in Istanbul, which can be defined as a mall and urban living space, hosts about 30-40k visitors/ day with its shopping units, eating-drinking places, cinema, performance arts center, public green space, and a public courtyard.

Zorlu Center, having Europe's most extensive green roof, has been selected as the research area. In this context, a survey was designed to measure the impact of the green roof, which has gained public space function, on the imaginary expression of Zorlu Center.

The survey consists of four parts:

Part 1: requires participants to fill in their demographic information.

Part 2: formulated to determine the participant's preference priority for the green element in the urbanized region. 
The 3rd part is based on the perception of the necessity of the green element in daily life to reveal the perceptual effect of the urban balcony on the artistic effect of the visitors.

The 4th part is aimed to investigate the impact of the green roof on the respondents' perception and the emergence of the green roof in their daily lives.

The selection of different age groups and a balanced distribution among the groups were taken into consideration in the selection of samples. The sample of the field survey was represented with residing in Istanbul; 18-24 age group 33; 25-31 age group 20; 32-38 age group 26; $39-45$ age group 18; 46 years and above, 20 people.

In January and February of 2019, 120 people in 4 different age groups were interviewed face-to-face with telephone, e-mail, and Whatsapp. Significant returns were obtained from 105 people, and the raw data collected from the area were evaluated with the statistical program.

In addition to its ecological and aesthetic objectives, green roof applications are gaining importance as a space that provides usage as a recreation area, which is very close to the urban residents.

\subsection{Presentation of Field Data}

In this section, the raw data compiled within the fieldwork have been processed according to the purpose of the study, and the series of analyses have been presented.

- Demographic information of participants

Most of the respondents were 30 years and older (64\%). The majority of the respondents were women $(70 \%)$. The fact that the participants are at different ages is essential in terms of determining the tendencies of different age groups for nature and comparing the requirements/demands of using the green space according to age distributions.

Table 1. Demographic information of participants

\begin{tabular}{lc}
\hline Age & Rate $\%$ \\
\hline $18-24$ & 16 \\
$25-31$ & 20 \\
$32-38$ & 26 \\
$39-45$ & 18 \\
$45+$ & 20 \\
Gender & \\
Woman & 70 \\
Man & 30 \\
\hline
\end{tabular}

According to the survey data, the 18-24 age range uses more space for shopping and cultural activities, but older adults use green areas more pleasant and frequent. However, it has been determined that there is awareness about green areas in every age group, and they are satisfied with these areas.

According to the results of the survey, the number of people who graduated from faculty is $48 \%$. It was determined that participants with higher education levels were more conscious about the benefits of the green roof than aesthetic value.

Table 2. Education level of participants

\begin{tabular}{lc}
\hline Education Level & Rate \% \\
\hline High School & 13 \\
University & 48 \\
Master & 33 \\
Doctorate & 6 \\
\hline
\end{tabular}

The study analysis showed that as the level of education increased, the knowledge about the green roof and the awareness of the benefits and functions of green roofs increased. This is because some of them have been informed about the green roof by reading books and articles. As Morau et al. (2017) pointed in their study, meantime the roof surface converted into a useful area, Zorlu Center became economically and functionally more efficient and had a better impact on the city.

- Green Preferences

As Ascione et al. (2013) revealed in their study, green roof application increases the value of the property with the aesthetic and practical thermal conductivity and energy saving; Zorlu Center gained value with its urban park as a green roof. The survey results show that most of the participants came to the shopping center for shopping and cultural activity and also visited the green area (38\%). This question aims to determine the role of the green space in the shopping center and to find out what the priorities of the participants are. Also, it is determined that the visitors, who use only the green area, to rest, being alone with nature, having a positive effect on psychological and health. In terms of social benefits (Dunnett \& Kingsbury, 2004), this study supports the statement "green roofs provide significant open space and have a positive effect on human health."

In the context of sustainable development (Hasim et al., 2018) and Zorlu Center provides an opportunity to 
increase the urban green space per capita by raising the quality of the environment in Istanbul.

As the frequency of coming to the shopping center increases, the preference of the using activity area is observed to be more prominent. Those who come to the lesser shopping center perform their visits mostly for shopping and cultural activities. The reason for the casual users for coming to Zorlu Center Mall is presented in Table 3.

Table 3. Reason for coming to Zorlu Center Mall

\begin{tabular}{lc}
\hline Reason & Rate \% \\
\hline For Shopping Only & 21 \\
Cultural Activity & 21 \\
Visits Green Field & 20 \\
Both Shopping- Cultural Activity And Visits Green Field & 38 \\
\hline
\end{tabular}

Under the limitation of the green and activity areas in Istanbul, people in the immediate vicinity use the Zorlu Center Mall to spend time in the urban park to be provided as a green roof. As Bakir Yigitbas (2018) revealed, high-density urban areas have been developed in Istanbul as other metropolitan centers. Due to the intense construction in the city centers, the amount of green space per capita decreases gradually.

The respondents emitted that they use the urban park in Zorlu Center Mall for the activity space (\%31), relaxing $(\% 30)$, its positive effects in terms of psychological and health $(\% 20)$, staying alone with nature $(\% 8)$. However, $8 \%$ of the respondents stated that they did not realize that there was a green space in the shopping center. The reason for the respondents to visit the green roof in Zorlu Center Mall is presented in Table 4.

Table 4. Reason to Visit the Green Roof

\begin{tabular}{lc}
\hline Reason & Rate $\%$ \\
\hline Positive effects in terms of psychological and health & 20 \\
For relaxing & 30 \\
Staying alone with nature & 11 \\
Activity space & 31 \\
Other & 8 \\
\hline
\end{tabular}

- Use of green roofs

In this section of the survey, the participants were asked about the benefits of green spaces to measure the awareness of green areas. $90 \%$ of the respondents stated that the green areas had a significant impact on human health, as claiming Dunnett and Kingsbury's (2004) findings. As Alcock et al. (2014) pointed in their study, the green area led people to be happier. It has been measured that the green roof had a positive impact on the development of the city. This finding supports Varey's (2017) statement. In terms of green areas, 75\% of the respondents think that cities are not in good condition in the context of urban quality of life. A vast majority of the participants agree that the urban environment will be improved and improved with the increase of urban green areas. Participants' views on urban green spaces and their environmental impacts are presented in Figure 1. 


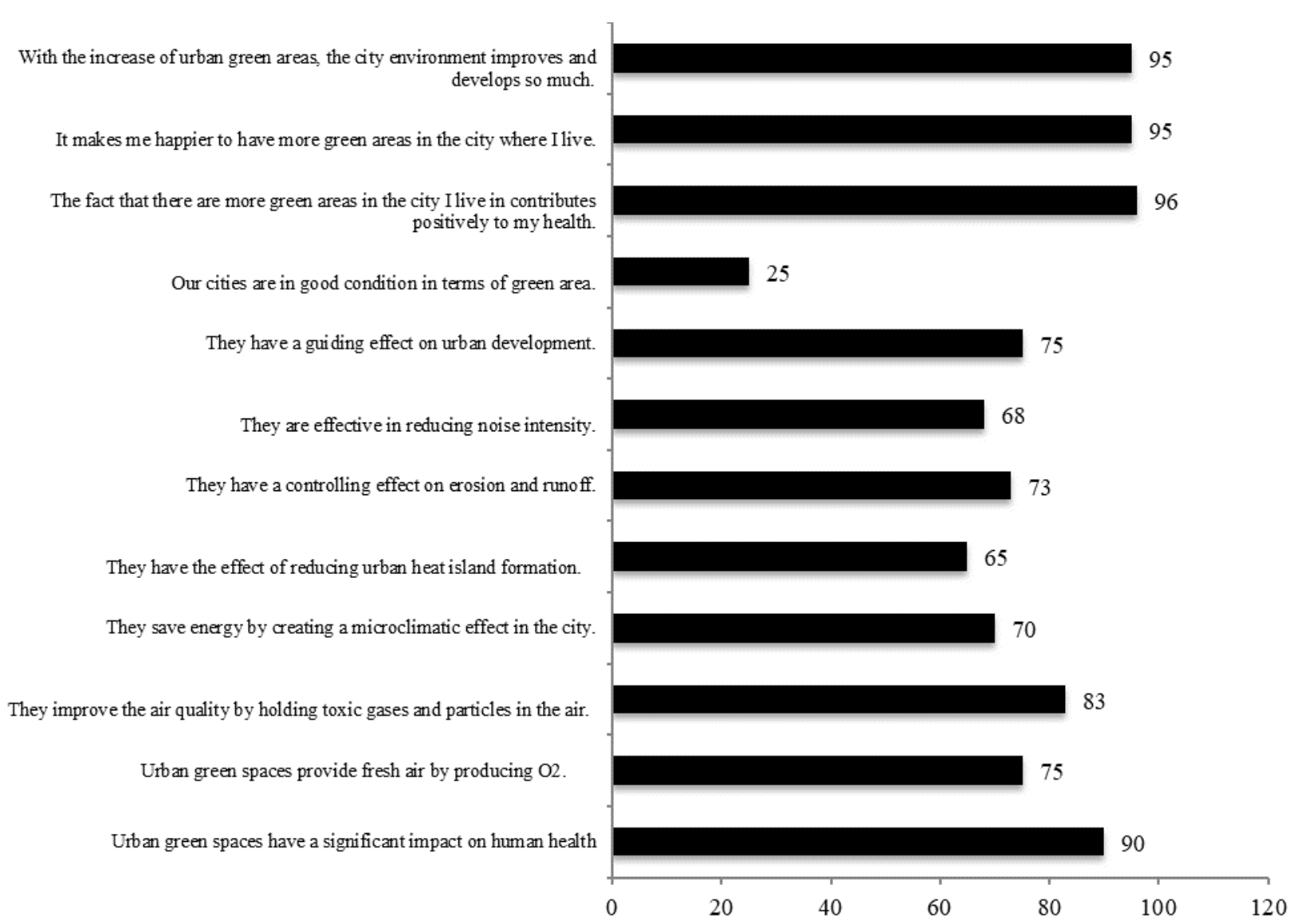

Figure 1. Participants' views on urban green spaces and their environmental impacts

Also, it has been noted that $45 \%$ of the respondents want to build green roofs in their buildings. However, the percentage of persons with information on the costs of green roofs and the maintenance costs is $21 \%$. The data obtained from the analysis indicated that most of the participants thought that there should be a green area in the city. Also, the presence of a green area that is much closer to their homes would contribute to the city and themselves. Participants' views on the protection and development of green spaces are presented in Figure 2.

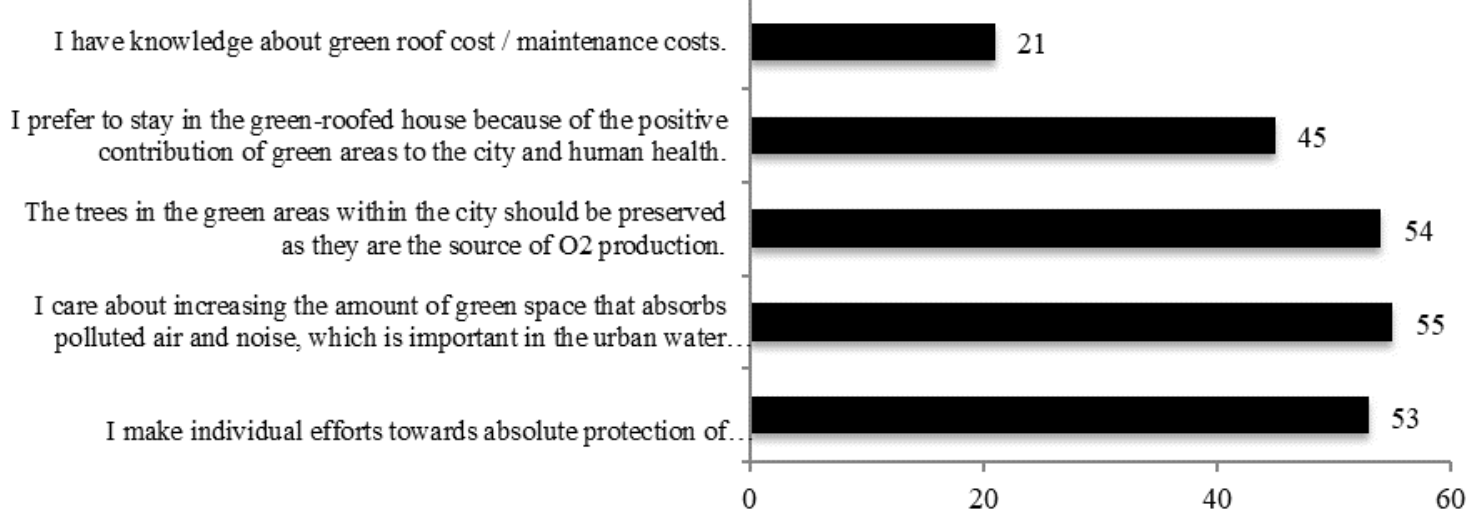

Figure 2. Participants' views on urban green spaces and their environmental impacts

\section{Conclusion}

This article presents the data from a survey conducted on visitors of the Zorlu Center Mall, Istanbul. The study was carried out to determine the level of awareness of the green roof of people, living in different districts of Istanbul with different age/gender and educational status. The most significant finding of this study is that almost all of the participants were aware of the necessity of the green roofs in the city. At this point, the question of how to raise awareness of urban green spaces is replaced by the question of how this awareness can be fed and transformed into environmental behaviors and activities.

The primary data obtained from this study are as follows:

Having a green element, at least like a green roof, helps to renew and revitalize the commercial environment in the urban area. 
Green roofing offers people a visual and sensory benefit in terms of psychological and physical health and quality of life.

The visual quality of the city silhouette can be improved with the green roof design.

Green areas are preferred for a better living environment due to the positive benefits of natural elements.

As a unique contribution of this study to the literature, people living in a metropolitan city, have a high level of awareness of green areas and their effects on their physical and mental health. Also, people have a very positive perception of urban green spaces. The green area in the shopping center provides a center of attraction for people other than shopping. At this point, this study contributes to future studies and investors' decisions, as it reveals the awareness of the public about the value of green roofs in a busy urban area.

\section{References}

Abkar, M., Mohd Shariff, M.K., Maulan, S. \& Davoodi, S.R. (2011). Determining the visual preference of urban landscapes. Scientific Research and Essays, 6 (9). 1991-1997.

Akther, M., He, J., Chu, A., Huang, J., Duin, B. Van A. (2018). Review of Green Roof Applications for

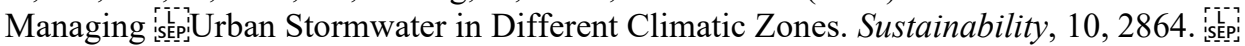

Alcock, I.P., White, M.P., Wheeler, B.W., Fleming, L.E., \& Depledge, M. (2014). Longitudinal effects on mental health of moving to greener and less green urban areas. Environmental Science \& Technology, 482 , 1247-55.

Ansari, M. \& Keshtkar, A. (2006). An investigation of green roof challenges in Iran, Monthly Journal of Road and Construction, (62), 62-55.

Ascione, F, Bianco, N., de' Rossi, F., Turni, G., Vanoli, G.P. (2013). Green roofs in European climates. Are effective solutions for the energy savings in air conditioning? Applied Energy 104, 845-859.

Bakir Yigitbas, S. (2018). Developments in Turkey’s Housing Market: Analysis of the Housing Bubble Risk, In Social Sciences Research in the Globalizing World, St. Kliment Ohridski University Press.

Bechtel, R.B., Marans, R.W., Michelson, W., Taylor, J.G., Zube, E.H., \& Sell, J.L. (1987). Landscape Assessment and Perception Research Methods. In R. Bechtel, R. Marans, \& W. Michelson (Eds.), Methods in Environmental and Behavioral Research (pp. 361-393). Van Nostrand Reinhold Co.

Benjamin, K., Bouchard, A., \& Domon, G. (2007). Abandoned Farmlands as Components of Rural Landscapes: An Analysis of Perceptions and Representations. Landscape and Urban Planning, 83(4), 228-244.

Benvenuti S. (2014). Wildflower green roofs for urban landscaping, ecological sustainability and biodiversity. Landscape and Urban Planning, 124(2014): 151-161

Berardi, U., GhaffarianHoseini, A., Ghaffarian Hoseini, A. (2014). State-of-the-art analysis of the environmental benefits of green roofs. Applied Energy, 115, 411-428

Clark, C., Adriaens, P., \& Talbot, F.B. (2008). Green roof valuation: a probabilistic economic analysis of environmental benefits. Environmental Science \& Technology, 42 6, 2155-61.

Coma, J., Perez, G., Cabeza, L.F. (2018). Life Cycle Assessment of Green Roofs. In Nature Based Strategies for Urban and Building Sustainability Eds Gabriel Perez Katia Perini, Elsevier.

Di Giuseppe, Elisa \& D'orazio, Marco. (2015). Assessment of the effectiveness of cool and green roofs for the mitigation of the Heat Island effect and for the improvement of thermal comfort in Nearly Zero Energy Building. Architectural Science Review. 58.

Dunnett, N. \& Kingsbury, N. (2004). Planting Green Roofs and Living Walls. Timber Press, Portland. Gedge, D. (2002). 'Roofspace - a place for brownfield biodiversity. ECOS, 22 (3/4), 69 - 74.

Erickson, D.L., Ryan, R.L., \& De Young, R. (2002). Woodlots in the Rural Landscape: Landowner Motivations and Management Attitudes in a Michigan (USA) Case Study. Landscape and Urban Planning, 58(2-4), 101-112.

Francis, L. Fjendbo, M., \& Jensen, M.B. (2017). Benefits of green roofs: A systematic review of the evidence for three ecosystem services. Urban Forestry \& Urban Greening, 28, 167-176.

Getter, K.L., Rowe, D.B., Robertson, G.P., Cregg, B.M., \& Andresen, J.A. (2009). Carbon sequestration potential of extensive green roofs. Environmental Science \& Technology, 43(19), 7564-70.

Goodey, B. (1971). Perception of the Environment. University of Birmigham. Centre for Urban and Regional Studies.Birmigham, R.R Ltd.

Green, T.L., Kronenberg, J., Andersson, E., Elmqvist, T., \& Gómez-Baggethun, E. (2016). Insurance Value of Green Infrastructure in and Around Cities. Ecosystems, 19, 1051-1063.

Hashemi, S.S., Mahmud, H.B., \& Ashraf, M.A. (2015). Performance of green roofs with respect to water quality and reduction of energy consumption in tropics: a review. Renewable and Sustainable Energy Reviews, 52, issue C.

Hasim, M.S. \& Kwong, Q.J. \& Hamzah, N. (2018). Sustainable Practices for Existing Building: Perspective of Local Authorities in Malaysia. International Journal of Academic Research in Business and Social Sciences. 8. 
Jim, C.Y. (2017). Green roof evolution through exemplars: Germinal prototypes to modern variants. Sustainable Cities and Society. 35.

Kopec, D.A. (2006). Environmental Psychology for Design, Fairchild Books.

Kuper, R. (2009). What's Up? Examining the Awareness of Green Roofs in Suburbia. Journal of Soil Water Conservation, 64 (5): 145-149.

Lee, K.E., Williams, K.J.H, Sargent, L.D., Williams, N.S.G., Johnson, K.A. (2015) 40-second green roof views sustain attention: The role of micro-breaks in attention restoration, Journal of Environmental Psychology, 42, 182-189,

Li, F., Zheng, W., Wang, Y., Liang, J., Xie, S.X., Guo, S., Li, X., \& Yu, C. (2019). Urban Green Space Fragmentation and Urbanization: A Spatiotemporal Perspective, Forests.

Li. Y. \& Babcock, R. (2014). Green Roofs Against Pollution and Climate Change. A Review, Agronomy for Sustainable Development, Springer Verlag/EDP Sciences/INRA, 34 (4), pp.695-705.

Liu, K., (2004). Sustainable Building Envelope -Garden Roof Sistem Performance, NRC-CNRC, RCI Building Envelope Symposium, November 4-5: 1-14, New Orleans.

Lynch, K. (1964). The Image of the City, MIT Press.

Morau, D. \& Rabarison, T. \& Rakotondramiarana, H. (2017). Life Cycle Analysis of Green Roof Implemented in a Global South Low-Income Country. British Journal of Environment and Climate Change. 7. 43-55.

Nawaz, R. \& McDonald, A. \& Postoyko, S. (2015). Hydrological performance of a full-scale extensive green roof located in a temperate climate. Ecological Engineering. 82. 66-80.

Newman, P. (2016). Sustainable urbanization: four stages of infrastructure planning and progress, Journal of Sustainable Urbanization, Planning and Progress, 1.

Peck, S.W., Callaghan, C., Kuhn, M., \& Bass, B. (1999). Greenbacks from Green Roofs: Forging a New Industry in Canada. Canada Mortgage and Housing Corporation, 11-12.

Pinter-Wollman, N., Jelić, A., \& Wells, N.M. (2018). The impact of the built environment on health behaviours and disease transmission in social systems. Philosophical Transactions of the Royal Society B: Biological Sciences, 373.

Qian et al. W. (2020) Migration of Rural Households and Citizenization of Migrant Workers. In: The Economy of Chinese Rural Households. Palgrave Macmillan, Singapore

Santamouris, M. (2014). Cooling the cities - A review of reflective and green roof mitigation technologies to fight heat island and improve comfort in urban environments. Solar Energy, 103, 682-703

Seyfang, G. (2010). Community action for sustainable housing: Building a low-carbon future, Energy Policy, 38(12). 7624-7633

Singh, P. \& Verma, P. (2017). Impact of Land use Change and Urbanization on Urban Heat Island in Lucknow City, Central India. A Remote Sensing Based Estimate. Sustainable Cities and Society. 32.

Stater, D. (2008). Green roofs: Sustainability from top down, A Senior Project, University of California.

Stovin, V., Vesuviano, G., \& Kasmin, H. (2012). The hydrological performance of a green roof test bed under UK climatic conditions. Journal of Hydrology, 414-415, 148-161.

Sutton, R.K. (2015). Introduction to Green Roof Ecosystems. Springer. 10.1007/978-3-319-14983-7.

Taylor, K. (2009). Cultural Landscapes and Asia: Reconciling International and Southeast Asian Regional Values. Landscape Research, 34. 7-31.

Varey, W. (2017). Apithology Systems Inquiry: Evaluation from Generativist Ontology. Systems. 5(22).

Velazquez, L. (2005). Organic greenroof architecture: Sustainable design for the new millennium. Environmental Quality Management. 14. 73 - 85.

Vijayaraghavan, K. (2016). Green roofs: A critical review on the role of components, benefits, limitations and trends, Renewable and Sustainable Energy Reviews, 57, 740-752.

Villagra, P. \& Vergara, G. (2012). Perceived visual landscape changes in a fire prone environment: A multimethod approach. Journal of Environmental Psychology. 32. 144-157.

Wolch, J.R, Byrne, J. \& Newell, J.P. (2014) Urban green space, public health and environmental justice: The challenge of making cities 'just green enough, Landscape and Urban Planning, 125: 234-244.

Wong, N. H., Wong, S. J., Lim, G. T., Ong, L. C. \& Sia, A. 2005. Perception Study of Building Professionals on the Issues of Green Roof Development in Singapore. Architectural Science Review, 48: 205-214. is.pep

Zahir, M.H. \& Raman, Sudharshan N. \& Mohamed, Mohd Farid \& Jamiland, M. \& Nopiah, Z.M.. (2014). The Perception of Malaysian Architects towards the Implementation of Green Roofs: A Review of Practices, Methodologies and Future Research. E3S Web of Conferences. 3. 01022. 10.1051/e3sconf/20140301022.

Zube', E. H., Sell', J. L., \& Taylor, J. G. (1982). Landscape Perception: Research, Application and Theory. Landscape Planning, 9(9), 1-33. 